ISSN 2411-9563 (Print) ISSN 2312-8429 (Online)
European Journal of Social Sciences Education and Research
September-December 2014

Volume 1, Issue 2

\title{
The unemployment of today and tomorrow in Romania
}

\author{
Mictat GARLAN \\ Research Institute for Quality of Life - Romanian Academy
}

Abstract

For any political regime the employment and unemployment of active population represents the most pressing social and economic obligation. in Romania, any comparative study before and after 1990, on $2 \times 2$ decades of different economic policies, can observe the damaging effects which they had forced privatization of state enterprises on the labor market, with over 1,000,000 declared unemployed in 1999, compared to zero unemployed in 1989. After this disaster, and after a short economic rehabilitation, it followed another crisis, with a further increase in unemployment of ANOFM, from 445,000 persons in 2009 to 626,960 persons in 2010 to 740,000 in 2011 of 674,000 in November 2012, 512333 persons in December 2013 to 724,000 persons in March 2014. These data indicate that in Romania the crisis is not over yet. in parallel to these developments there have been published the analyzes of the National Commission for Prognosis, but with some significant deviations in two directions. On the one hand, the calculations are made on the formula BIM records, and on the other hand, they are in the direction of a lower estimates. So, in the estimates of performed forecasts for the years 2014 -2017, with trend analysis and analysis of previous years, the total number of unemployed in 2011 was to be of 730200 persons. in 2012 the total number of unemployed was to be of 701,200 persons, in 2013 of 726,000 persons, of 705,000 persons in 2014, of 690,000 in 2015 and of 685,000 in 2016. Without contesting the effort to accuracy of this Commission and the fact that any forecast includes a dose of risk too, there are obviously immeasurable variables that were not taken into account. We refer to the quality of business environment, revenues polarization, with decreasing trends in wages, to labor migration especially medium and high qualified. We refer to the existing difficulties in the allocation of development credits, to the corruption of officials from the local councils the excess of electoral concerns of governments, with the necessity of different approaches for each of them. With this supplement of fren factors we can say that on prospective 2 years, the registered unemployment from National Institute of Statistics, will not fall below 740.000 persons. To these things, it must be added the volume of more than twice unregistered persons, which means a total of approx. two million persons, this being the actual estimation of the non-employed population, to which has reached in Romania today.

Keywords: privatization, unemployment, concepts, causes, effects, ILO rate, ANOFM rate, black job, forecasts

\section{Introduction}

After 5 years of global economic recession, which appeared from the sovereign debt crisis with austerity policies, but also because of some banking speculations running out of control, it was natural that in the top of issues of social interest to be situated the unemployment and insufficient income. Thus, in a Eurobarometer in autumn 2013, to the question: what are the most important issues facing your country on the first placed fear of unemployment with $49 \%$ in August 2013 and of $51 \%$ in September, 2013; on the second in the same period (of August and September) placed the economic situation with a percentage of $33 \%$, which is actually a general decline in living standards. in the year 2013 , also the Romania communicated unemployment was only $6.7 \%$, the most affected countries being Greece with $26.4 \%$ and Spain with $26.3 \%$. But, these figures are relative because an analysis by age groups, at the top of a very early and in whole southern European youth unemployment rates are $100 \%$ higher, respectively, $58.4 \%$ in Greece, of $55.7 \%$ in Spain, $38,2 \%$ in Portugal, or $37.8 \%$ in Italy. in the case of Romania, the relativity data comes from several sources. A reference example in the recent history of Romania was in December 1999 when it registered over one million unemployed, but to Eurostat, in 2000 it has communicated a rate of only $7.3 \%$. These huge increases of registered unemployment, which represented the greatest crisis in the socio-economic history of the country, were silently neglected by the authority's time. in our opinion, this time require a remember both for risks involved in, but also for the fact that the employment of active population is the first and most urgent requirement of any political regime, regardless of its guidance.

To understand the magnitude of such events requires a retrospective on two decades of different economic policies, one of them national-communist, before 1990 and another after 1990, of such a so-called shock transition, towards a democratic regime. in a paper published in 1994, a former Minister of public administration mentioned that:"In industry in 1992 the activity was carried out in 2,920 companies with 8 million employees, in which 1.817 in public property with 2,782,800 341 employees, in privately property with 44,800 workers, 35 in mixed property with 30.800 employees and 727 in cooperative 
ISSN 2411-9563 (Print) ISSN 2312-8429 (Online)
European Journal of Social Sciences Education and Research
September-December 2014

Volume 1, Issue 2

property with 174.400 employees" (O. Cosmancă1, page 22.). This "Communist economic inheritance" with nearly 3000 industrial enterprises, made with great efforts, each of them with its history, in only 10 years of stupid transition, corruption and incompetence in Government, was destroyed in a percentage of $70 \%$. One example was Automobile ARO-Campulung Muscel enterprise, with 40,000 jobs for the population of the region, where in 1990 started a large stealing of parts of the unit, both from the employees as well as the management.. Is reached as a automobile ARO to sell into a $50 \%$ damage for each item. and after 2 years, the State, which was the owner of the company, stopped payment huge damages which gathered and the unit closed. But nobody been held accountable, nor any of the employees anf of the management. in the year 1990 in Combinatul de Utilaj Greu from lasi worked 12,000 employees, this unit being a major producer of "welded structures ", respectively machine tools, wagons, tanks, with manufacturing secrets of "great importance" and with an guaranteed sales market in the world. After 1991, the unit became company Fortus S.A. and it entered into entered into "the process of privatization", but with repeated failures that have disorganized the activity, have reduced the orders, the employees retired, and in 2008 the unit went into bankrupt with debts of millions euros. Another great industrial colossus, set up on a foundation of a firm in 1916 was producing Combinatul Siderurgic Victoria Călan, with 20,000 employees from Hunedoara area in 1989. Between 1990-2000, to the management difficulties as a great state enterprise, added the internal difficulties with stealing and selling of scrap metal from the unit, in desperately practiced by all unit heads, until it was divided in 1998 in 12 companies. But the plummet with damages paid from the state budget continued. in 2000, the remaining companies were privatized through taking over of multinational Arcelor- Mittal, and the staff has been reduced to 1,000 employees. Another case was Semănătoarea Bucureşti Enterprise. in 1990 it had 7,500 employees and it produced 3,500 combines per year, in competition with the most reputable companies in the world. in 1992, it entered ,in the process of privatization" too, which resulted very quickly to the output block. Following three unsuccessful auctions, by accumulating large debts and by refusing an offer of $\$ 50$ million from New Holland company, in 1998 with the agreement of the union committee of the enterprise, the State property Fund sold $56.7 \%$ of its shares, MYO SA - Bucharest Company and the staff has been reduced to 100 employees. So, we go on with many other examples of "1256 enterprises from Romania closed after 1989", which had between 1,000-20,000 employees and from which today remained just a list on the internet. We mention that this analysis does not question of such assessments, "the communism up ", at least for the fact that there were examples of successful privatizations such as Dacia - Piteşti, Aerostar - Bacău, Silcotub Zalău, Azomures-Targu Mures, synthetic diamonds Rami-Bucharest, enterprises that have won on the market and even raised jobs. But, to major shocks with more than one million unemployed in the years 1993 - 1994, which were also resumed in 1999-2000 with over a million unemployed, we obviously believe that no one has learned anything from these events and at that time there was no political interest and no model of economic thinking for Romania. Everywhere missed sanctioning systems, control systems, prevention, audit, management and economic guidance of these processes. in this respect, an evidence was in 2004 when Năstate Government privatized the Petrom Company by selling it to package with Arpechim Refinery to the Austrian Company OMV-Österreichische Mineralölverwaltung, but then, no one in that Government did not realize it would be bankrupt Oltchim SA -Rm. Vâlcea Company, Arpechim Refinery being the main supplier of raw materials for Oltchim Rm. Vâlcea. We note that Arpechim had 13,000 employees in 1995, compared to today when when it comes to its closing, being full of debts, while former Combinat Chimic - Rm. Vâlcea, respectively existing company Oltchim SA had 5,200 employees in 1990, compared to 3.538 in 2010 . As a culmination of economic commercial spirit of this government, we have to add that in this privatization of great importance it was included not only the sale of refineries and petrol stations in Romania, but also its oil deposits of $\$ 14$ billion at that time, while OMV firm was 11 times less than Petrom SA (!). After this catastrophic privatization, the number of employees from Petrom-OMV has dropped from 50,000 in 2004 to 26.736 in 2010. Also today, after 10 years of transaction conduct complex negotiations with Petrom - OMV for returning to the Romanian state of the Arpechim Refinery - Piteşti, because it appeared investors who intended to purchase company Oltchim SA, but only with the Arpechim Refinery ! This defective economic and political thinking was characteristic for the most of the processes of privatization and in all governments since the year '90. in order to maintain the market, legal transformation, restructuring and large capitalization of Communist companies, slow therapy would be more appropriate and it have resulted to avoid to their collapse, with 4 million people left homeless as starving.

1 Octav Cosmancă and collaborators,, Judeţele şi oraşele României în cifre şi fapte,

Publishing the Department for Local Public Administration, Bucharest, 1994 
Table No. 1 Evolution of unemployment in Romania between 1991-2005

\begin{tabular}{|l|l|l|l|l||}
\hline Year & $\begin{array}{l}\text { Number of registered } \\
\text { unemployed at the end of } \\
\text { the year }\end{array}$ & $\begin{array}{l}\text { Unemployment } \\
\text { rate Registered }\end{array}$ & $\begin{array}{l}\text { Number of un } \\
\text { employed ILO } \\
\text { (thousands of people) }\end{array}$ & $\begin{array}{l}\text { Unemployment } \\
\text { rate ILO (\%) }\end{array}$ \\
\hline 1991 & 337,4 & 3,0 & - & - \\
\hline 1992 & 929,0 & 8,4 & - & - \\
\hline \hline 1993 & $1.164,7$ & 10,2 & - & - \\
\hline \hline 1994 & $1.323,9$ & 10,9 & 971 & 8,2 \\
\hline \hline 1995 & 998,4 & 8,9 & 968 & 8,0 \\
\hline 1996 & 652,0 & 6,2 & 791 & 6,7 \\
\hline 1997 & 816,3 & 9,3 & 706 & 6,0 \\
\hline \hline 1998 & $1.025,0$ & 10,4 & 732 & 6,3 \\
\hline \hline 1999 & $1.130,3$ & 11,8 & 790 & 6,8 \\
\hline \hline 2000 & $100.7,1$ & 10,5 & 821 & 7,1 \\
\hline \hline 2001 & 826,9 & 8,8 & 750 & 6,6 \\
\hline 2002 & 760,6 & 8,4 & 845 & 8,4 \\
\hline 2003 & 658,9 & 7,4 & 692 & 7,0 \\
\hline 2004 & 557,9 & 6,3 & 680 & 6,8 \\
\hline 2005 & 523,0 & 5,9 & 650 & 6,5 \\
\hline
\end{tabular}

Source: Statistical Yearbook of Romania 1992 - 2004; Statistical Bulletin 1997-2006

Investigations in households labor (AMIGO) 1994-2005

It should be noted that the phenomenon of large scale unemployment as a result of this transition, did not exist during the communist period in Romania, but it formally imposed together with these processes since 1991 when the Law no. 1/1991 on social protection of the unemployed and their professional reintegration came into effect. Also, a surprise of these disastrous situations, with millions of registered unemployed, was that Romania communicated to Eurostat in 2000 an unemployment rate (ILO) of only $6.8 \%$ ! - see table no.1.

It is very true that on the labor market, as a reality in motion, between the phenomena of employment, vacancy, part time work or inactivity, are difficult to establish differences, but there were accepted some concepts of statistical practice, thus:

The total active population includes the entire the available labor force for producing goods and services, including that one that exceeded a limit of age, variable from one country to another. The active population includes the employed population and the unemployed together and it is representative for employment of population and labor supply.

The active civil population includes the employed population and the unemployed, without military personnel within.

The employed civil population includes the same categories of persons, without military personnel within. in Romanian statistics, the employed civil population includes the individuals older than working age of 16 years, having a job where carry out activities which generating income, except for the military, of the Ministry of Internal, security services and for employees in the public and political organizations.

The active unemployed population represents the one that refers to the unemployed.

Inactive population represents the population which is not employed at work but it was not registered as unemployed.

For example, based on these analytical indicators it can be calculated the gross rate of activity for population by comparing the active population to the total population or employment rate by reporting employed population, either on age intervals 
ISSN 2411-9563 (Print) ISSN 2312-8429 (Online)
European Journal of Social Sciences Education and Research
September-December 2014

Volume 1, Issue 2

of the population in labor, either to the available work resources, either to the total population, each of them with significations. But, in terms of operating mode with these concepts and providing indicators for the labor market, between Romania and the European Union there are significant methodological differences starting right at the level of definitions. International Labor Office (ILO) defines the unemployed person as person over the age of 15 years and cumulatively meets the following three conditions: those who don't have a job (even he was fired or request the resumption of work after a voluntary interruption); they are at the first search for a job, using in the last 4 weeks different methods to fiind it (even those one still employed in a part time work or still in the temporary work period) and who can start work in the next two weeks, to the first offer of a job.

As compared in Romania, in accordance with the unemployment Law no. 76/2002, with subsequent amendments and completions, the unemployed are people with aged at least 16 years, recorded by the services of the National Employment Agency (ANOFM), which cumulatively meet at least six conditions respectively: persons who are looking for a job; did not comply the retirement conditions according to the law; persons able to perform a work in complete state of physical and mental health; people who don't realize or obtain incomes from legal activities, lower incomes than the reference social indicator 1 ; people who can start work immediately if they find a job and have a minimum contribution period of 12 months in the last 24 months, preceding the date registration of unemployment aid compensation request. So, the unemployment rate as the main analysis indicator of labor market is calculated in two ways:

Unemployment rate in the sense of the International Labour Office is calculated based on data from - Employment inquiries carried out in households (LFS), representative at the national level as - ratio between the number of unemployed people as defined according to the criteria of the International Labor Office (ILO) and total active population, indicator calculated by the National Institute of Statistics, as follows:

total unemployed ILO from inquiries of LFS

Unemployment rate $($ ILO) =

active civil population

While the unemployment rate, indicator calculated by the National Agency for Employment from Romania (ANOFM), is determined by its registrations and civil active population, communicated by the National Institute of Statistics. More precisely, the unemployment rate is determined as the ratio between the number of unemployed indemnified persons, by the county agencies for employment, respectively ANOFM and the municipality of Bucharest, relative to civil active population, according to the formula:

total registered unemployment persons

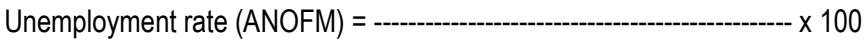

active civil population

As a result, the differences concerning the unemployment rate are high because NEA takes into account only the unemployed persons. Romanian unemployment law, respectively Law no.76/2002, with subsequent amendments and additions, put a special emphasis on the stages of contribution of the unemployed, the main orientation of this law being the assurance the funding of the budget of unemployment and less the reality employment relations / unemployment in Romania.

Thus, unemployment compensation are paid monthly, for 6 months in quantum of $50 \%$ of the reference social indicator, but also differentiated according to the stages of contribution, in the following way: 6 months for a period of at least one year of contribution; 9 months for a period of at least 5 years; 12 months, for a period of contribution higher than 10 years. for those who have contributed at least one year, the unemployment compensation is $75 \%$ of the social indicator. Other differences by contribution period are: $3 \%$ to a contribution period of at least three years; $5 \%$ to a contribution period for at least 5 years; $7 \%$ to a minimum contribution period of 10 years; $10 \%$ for persons with a contribution period of at least 20 years. The only admitted categories of unemployed without compensated stages to the social security contributions are: secondary and higher education graduates; graduates of special schools for persons with disabilities who within 60 days after graduation were not able to employ; persons before military service were not employed and that within 30 days after

1 The reference social indicator value is 500 lei, according to the article 40 from the Law no.76 from 2002

with subsequent amendments and completions, updated in 2014, published on the internet. 
ISSN 2411-9563 (Print) ISSN 2312-8429 (Online)
European Journal of Social Sciences Education and Research
September-December 2014

Volume 1, Issue 2

the end of this stage could not employ themselves. Basically, this law has especially in view to achieve a balance accounting between indemnified / non-indemnified less knowing of real situations of the economy.

Based on these procedures, the unemployment rate by the National Institute of Statistics of Romania1 was of $7,5 \%$ to an active population of 9.732 .000 people, of which 9.001 .000 employed persons and 731.000 unemployed persons, while that communicated in March 2013 by the Ministry of Labour, Family and Social Protection and Elderly Persons (MMFPSPV) based on registration ANOFM2 was lower, at $5.58 \%$ value. in the same communication, MMFPSPV indicated that the number of unemployed would have been only 492427 people, of which 309.379 indemnizate and 183.048 nonindemnizate. The percentage of unemployed indemnified persons was an average of $62.83 \%$, being higher compared the previous months, their percentage in some counties being much larger. for example, during the same period, at county level, the top 10 places, the percentage of the unemployed persons was represented by counties: Teleorman 79,15\%, $77,93 \%$, Dolj 77,93\%, Galaţi 77,63\%, Buzău 77,11\%, laşi 76,51\%, Vaslui 76,03\%, Satu Mare 75,64\%, Vrancea $74,34 \%$, Brăila $73,87 \%$, Covasna $72,90 \%$, etc. Also, differences in unemployment rates between the two institutions may occur because in fact, many people declare in inquiries LFS unemployed of the National Institute of Statistics, but no longer registered at county agencies of the NEA. The problem is permanently between the two unemployment rates there is a difference of 2-3 percentage points, lower the NEA compared to INS, which means there is a difference monthly of approx. 200,000-300,000 unemployed people, respectively very high values, resulting only from calculation methodology !

On the other hand, compared to necessity of estimation real situations, differences in these calculations take into account the total occupied active population, respectively the total number of employees. in this connection, a study made in 2014 by the National Trade Union Bloc put in comparison the registrations of employees at the National Agency of Fiscal Administration (NAFA) 6.55 million workers in 2013, compared with 6,48 million registered employees in the same year at the National House for Health Insurance (CNAS). Calculation differences are even greater between insured persons from the CNAS, compared with those of the National House of Public Pensions (CNPP), where 4.5 million employees pay contributions to the pension fund and 6.5 million employees pay contributions to the health fund. Basically, five different public institutions, namely: the National Agency for Fiscal Administration the National House for Health Insurance, National Institute of Statistics, The Labor Inspection the National House of Public Pensions, and a private one, respectively the Association for Pension Funds with retired registered 6,03 million in October 2013-have different statistics about the employed population.

In 2013, the largest differences were noted between those 6,55 registered employees of millions NAFA and 4.3 million people occupied communicated by the National Institute of Statistics. To the question referred by Press of this Institute about the differences between the active population, the number of employees reported in the monthly bulletins (4.3 million people) and low unemployment, of $7 \%$, NIS answered that: "The number of 4.3 million people comes from the monthly research on earnings, which does not include the number of employees small units with less than 4 employees nor armed forces or their assimilated and it has coverage and different reference period compared to the reference period of the survey Labor in households". Referring to unemployed, the answer was: "The number of people registered as unemployed about 730.000 is calculated as a percentage to the total active population, regardless of whether a portion of the active population, are working on the black or is away from the country. Romanians leave the country temporarily to work not included in the system if you are working through employment agencies". Basically, this answer shows that only those officially registered with contracts of employment is the number of employees included in the monthly bulletins (4.3 million). in other words, the very high number of over 2 million people seeking to work abroad, who maintained their domicile in Romania, do not appear in the Employment inquiries carried out in households (LFS-AMIGO) and surveys as a result in estimates of the National Statistics Institute

With all these figures relative can make an analysis on the relationship of job seekers using subcategories with restraint data in annual reports NEA. Thus, towards the end of the year 2013, the unemployment rate registered this institution was increasing compared to the year 2012 when on 31 December 2013 had a value of 5,65\%. Total number of registered unemployed persons (registered entered plus unregistered unpaid has known a fluctuating trend from 513.349 persons in January 2013, to 428.866 in September 2013 and to 512.333 by the end of 2013.

1 National Institute of statistics, Press release nr. 148 of 21 June 2013, published on the internet

http://www.insse.ro/cms/files/statistici/comunicate/somaj/somaj_Ir_13.pdf

2 Labor Ministry, Press Release - Employment, Mobility, Unemployment and Social Protection of the Unemployed people, published on the internet address: http://www.mmuncii.ro/j33/images/buletin_statistic/somaj\%20trim\%20l\%202013.pdf 
ISSN 2411-9563 (Print) ISSN 2312-8429 (Online)
European Journal of Social Sciences Education and Research
September-December 2014

Volume 1, Issue 2

The number of unemployed registered persons with unemployment benefits (in terms of stock) has seen also dropping from 208.698 in January to 163.007 people in September and a rise in the last months of the year 2013, reaching 31 December 199.626 at people. in general, increases in the number of unemployed in the summer period correspond to periods of registration in the records, as the young unemployed, high school graduates, while during winter the price increases represent the normal tendencies caused, mainly, seasonal activities, 2013 being similar to the year 2012.

Also, the number of unemployed has experienced decreases in benefits, from 208.698 in January to 163.007 people in September and increases at the end of 2013, to 199.626 people. in general, the increasing number of unemployed during the summer periods correspond to the record of the young high school graduates. Comparatively, in winter the increases are normal, and is caused mainly by seasonal activities, 2013 being similar to the year 2012.

The records related to gender, it is found that the female unemployment rate was during the analysis period, less than that recorded among men. While the number of unemployed from rural areas is consistently higher than those in urban areas.

Since January 2013 and by the end of December the collective included 53.059 layoffs, but practice has shown that many economic agents have reviewed the restructuring programmes, so that the actual personnel layoffs in January and December of 2013 were 22.791 people, i.e. a large share of around 43 percent of the total laid off. What would indicate the economic environment of business foresight capacity, relatively low.

It should be noted that in accordance with art. 70 of the labour code, employers are obliged to inform the territorial agencies of labour, within which they are established, the notifications regarding collective redundancies we intend so that people affected by redundancy are entitled to social welfare in accordance with Law no. 76/2002 concerning unemployment insurance and stimulation of employment, with subsequent amendments and additions.

About job vacancies registered in 2013, they were higher than in the year 2012. If in 2012 the number of job vacancies reported by employers was 454.366 in the year 2013 the total number of these was 489.024 . Of the total of such vacancies registered in 2013 and made available to for people looking for a job, registered in NEA agencies, 53.690 posts have been repeatedly declared by employers against 44.395 jobs declared repeatedly during the same period of the year 2012. Be noted that, while the number of job vacancies increased in 2013 with 7,63\% compared with the year 2012, there has been an increase in the number of registered unemployed in 2013 compared with 2012 with $11,28 \%$.

The main 10 trades as significant vacancy, declared during the period January-December 2013, were: unqualified worker in the demolition of buildings, masonry lining, mosaic tiles, tiles, tiles, parquet; laborer in the textile industry; truck driver / truck machine; seller; freight handler; laborer to the assembling / mounting pieces; confectioner-assembler of textile articles; trade worker; laborer at maintenance of roads, highways, bridges, dams; laborer for packaging solid and semisolid products.

From the evolution of ratio paid unemployed / registered as unpaid persons in the records of employment agencies, it appears that the number of those registered as unpaid recorded high values throughout the year 2013. This represents a big disagreement with permanent basis, between Register of NEA job offers and qualifications unemployed, registered at these local agencies. So, the number of those registered as unpaid was during the year 2013 between 265,000 - 336.000 people / registered as unpaid unemployed persons are, as a rule, persons who either came out of the period of redundancy without having to qualify or do not meet the legal conditions for the redundancy, but resorting to the services of the Agency to find a job. These are people without preparation, or lower education, mostly from rural areas, long-term unemployed, young people under the age of 25 years are over 6 months unemployed and adults older than 25 years, who are unemployed for over 12 months.

In 2013 the structure of unemployment by levels of training was the following:

$71,44 \%$ unemployed persons with no education and primary education,

secondary education and vocational education,

$21,62 \%$ unemployed persons with secondary educational level and post-secondary,

$6,94 \%$ unemployed persons with university studies. But in general, people with a high education and training appeal in the smallest proportion to these agencies.

Regarding the age structure of registered unemployed, we note that the groups groups that are found most unemployed are in the 30-39 years 40-49 years. Both groups have recorded the maximum number of unemployed throughout the year 2013 , followed by group under 25 years. 
Starting from a number of 493.775 registered at national level at the end of 2012, during the year 2013 were registered the following inflows and outflows:

- the actual entries in the records of unemployment were of 826.142 persons,

- $\quad$ effective outflows of unemployment records were of 807.384 people.

- $\quad$ from the total inflow, 659.484 people who use for the first time to employment services, for support in finding a job.

- At the end of December 2013, occupations with the highest number of unemployed were:

- unqualified workers in mixed farms, 82.726 people

- unqualified workers in manufacturing, 65.404 people

- $\quad$ unqualified workers in public works, 36.634 people

- unqualified in construction of buildings, 35.103 people

- $\quad$ handle merchandise, 27.083 persons,

- $\quad$ builders and fitters structural metal, 15.246 people,

- $\quad$ sellers in stores, 9.276 people,

- $\quad$ other categories.

Regarding the evolutions in unemployment entries as a result of current and collective dismissals of staff (181.886 people) and of the outflows from employment (319.685 people), in 2013 it may be noted that the number of outflows due to employment was significantly higher than the number of people entering through layoff, except for the months of January and December when the obvious seasonal character shows its effects.

Overall, in 2013, the ratio of people who left through employment and those ones unemployed through layoffs was almost 2 to 1 . From the total number of 181.886 people became unemployed due to layoffs during the year 2013 , only 13.787 people come from layoffs as a result of application of the restructuring and privatization programmes of various sectors of activity, the rest of 168.099 persons from came from current layoffs. The areas that have been the most layoffs were mainly:

- civil engineering works, 2.573 people,

- construction of buildings, 2.039 people,

- manufacture of chemicals and chemical products, 1.628 people,

- land transport, transport via pipelines, 1.596 people,

- activities of services in information technology, 1180 persons,

- investigation and security activities, 905 people.

Regarding the distribution by regions, by the end of 2013 , the regions with the highest unemployment rates were recorded in South West $(8,57 \%)$, South $(7.46 \%)$ and South-East $(6.67 \%)$ regions where rural activities are predominant. There is a discrepancy within regions too, where predominantly agricultural counties coexist with the most developed counties. for example, in the South-West region, there were discrepancies between counties, in regards registered unemployment rate: the maximum level has been reached in the counties: Mehedinţi $(10,10 \%)$ and Dolj $(9.03 \%)$ and the minimum one was reached in county of Vâlcea $(6,10 \%)$.

The counties with the highest rates of registered unemployment rates were: Mehedinţi $(10,10)$, Teleorman (10.05), Galaţi (9,05 Dolj $(9.03 \%) \%)$, Vaslui $(8,74 \%)$ and Dâmboviţa (7.50 percent). The counties with the lowest rates with registered unemployed were: Timis (1.80\%), Bucharest $(2.06 \%$, Arad (3.19\%), Cluj $(3.59 \%)$ and Maramures $(3.85 \%)$. in other counties, the unemployed registered rate at NEA varies between $4,04 \%$ in Bihor county and $7,83 \%$ in Olt county. Between these percentages can be observed very large county differences of about 1/10.

Table nr. 2 Distribution of unemployment rate with registered unemployed at the county agencies of NEA in 2013Source: NEA activity report for the year 2013, published online at the following address:

http://www.anofm.ro/files/RAPORT\%20ACTIVITATE\%20ANOFM\%20\%202013.pd 


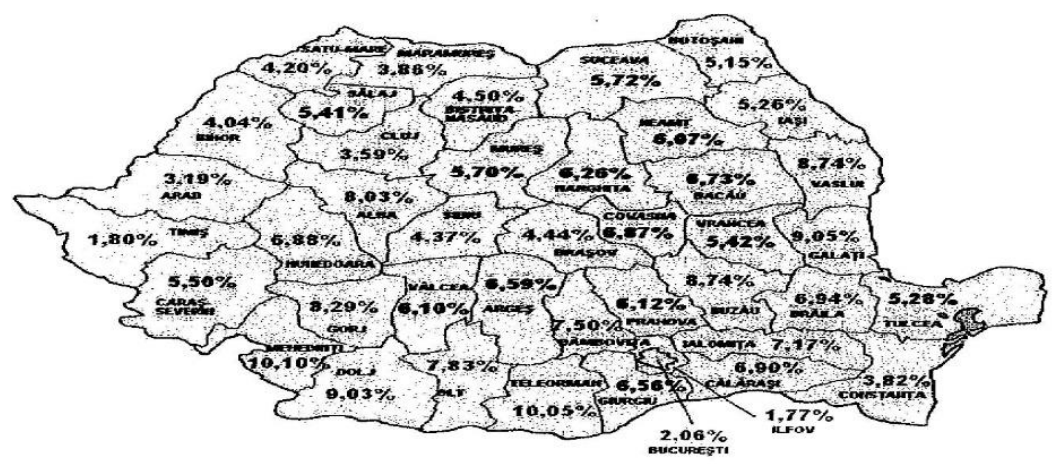

But, for overall, Romania is presented with a population of 20 million people in 2013 , in which there are 4.3 million employees (from which 3,1 million in the private sector plus 1,2 million in public institutions), 5.3 million retirees and 7,0 million socially assisted persons. About 3 million people are not present in any statistics, they either work illegally or working abroad or working in subsistence agriculture. Due to the absence of at least 2 million jobs and with a ratio of 1,21 retirees to an employee as well as another report of 1.62 to a employee social assistance These relationships demonstrate a dysfunctional economy through which Romania, on a long term is sentenced to a definite backwardness. Serious is the fact that from various causes, the unemployment has a tendency to increase, the most obvious being the dissolution of over 400,000 jobs between 2010-2012 with losses of approx. 11 billion euros from wages, a difficult situation to recover and only on long term.

Table No. 3 The evolution of unemployment in Romania from

National Institute of Statistics communications in the period 2008 - 2014

\begin{tabular}{|l|l|l|}
\hline Year & Total unemployed ILO & The unemployment rate \\
\hline 2008 & 575.000 persoane & $5,8 \%$ \\
\hline 2009 & 681.000 persoane & $6,9 \%$ \\
\hline 2010 & 725.000 persoane & $7,3 \%$ \\
\hline 2011 & 730.000 persoane & $7,4 \%$ \\
\hline 2012 & 701.000 persoane & $7,0 \%$ \\
\hline 2013 & 730.000 persoane & $7,3 \%$ \\
\hline $2014^{*}$ & 702.000 persoane & $7,1 \%$ \\
\hline${ }^{*}$ After an estimate disclosed in April 2014 \\
\hline
\end{tabular}

But, in our opinion, the real question has its origins in the destruction of 4 million jobs in the so-called transitional period 1990-2000 in Romania, after which 4 million people of working age had to continue living in their absence. This percentage of $20 \%$ of the population entered into long-term unemployment, that most of them either renounced looking for a job, or withdrew in the underground economy or subsistence agriculture, until they come out in all statistical and of employees and unemployed. Subsequently, the remained active population unemployed and without purchasing power and abandoned the country and after the year 2000 has reached an unprecedented phenomenon in its history, the migration of more than 2 million people to Western Europe. This is the main cause of a whole procession negative effects: on pension funds, on the relationship between the employees and retirees, with the complex phenomenon of demographic aging, and others.

It is obvious that in the absence of major reforms of the country's re'industrialization, there will be a massive decrease in population in Romania, estimated by the National Institute of Statistics, from 20 million in 2013 to 12 million inhabitants in the year 2060. 
ISSN 2411-9563 (Print) ISSN 2312-8429 (Online)
European Journal of Social Sciences Education and Research
September-December 2014

Volume 1, Issue 2

Another important cause of unemployment in Romania is deficit of professional orientation of youth, with a non-functional adaptation to the labour market. Although youth unemployment has passed $25 \%$, many employers say they cannot recruit young people for jobs because they don't correspond to offer and they don't have sufficient experience in this field. in the "Job fairs" of employment agencies the most deficient vacant positions are in the fields of civil engineering, repair ships, production of electronic and electrical components, engines, textiles and ready-made clothes, wholesale and retail, including from bakery.

Also, it is noted that, for people with higher education, a large number of faculties produce diplomas and specialists that nobody needs. Recruitment services know well how difficult are found jobs for graduates of faculties from: tourism, justice, European studies, public relations, management, public administration, psychology, sociology, philosophy or letters, because the structure of higher education is not directed to the labor market trends of today. The most popular specializations are: medicine, pharmacy, informatics, automatics, electronics, agriculture and foreign languages. in order not to spend the years of youth life, this educational and vocational orientation and selection process must be controlled on all levels of education. On graduation, to become independent, in addition attached to information acquired, any young person in which state and family have invested funds, time and labor, must have strong professional aptitudes. Unfortunately, this important section of juvenile education is not performed. As a proof, the complexity of modern professional requests, nowadays, most graduates of any level, used to stay one more year at home, "to reorient themselves on the labor market". Others, in finding a job on the capacities, will spend many years of life. for example, in a study done in April 2014, by Samsung Electronics Company from Romania, in partnership with the Ministry of National Education, on a sample of approx. 4,000 secondary school students, between 14 years old and 19 years old, from 15 secondary schools in the cities of Timişoara, Arad, Oradea, Baia Mare, Bistriţa, in the top of most popular were the following careers: lawyers, $15,4 \%$ programmer $12.9 \%$, actor $11.4 \%$, computer system engineer $9.8 \%$, surgeon $8.3 \%$, business manager $8.2 \%$, architect $5.5 \%$, secondary school teacher $5.4 \%$, medical psychologist $5.2 \%$, cardiologist $4.7 \%$. We note that these jobs have a liberal character.

But, with such trends, if we consider only this period of age, and those 700,000 unemployed persons already registered at the NEA, as relative are these estimates, about $30 \%$ of these young people will enter to the employment agencies, until the expiration of the legal period of three months after graduation. Due to the fact that in 2014 only about 130,000 young people have graduated secondary school, approx. 43,000 will be registered at county agencies for employment, so the minimum number of unemployed in Romania in December 2014 will be at least 743,000 of unemployed people in payment. To these estimates are also added other unemployed people because large steel companies are in recession. in 2014, Arcelor Mittal Combinates from Galati and Hunedoara proposed to employees going into voluntary unemployment. Other 300 layoffs were announced at Hunedoara Energy Complex. Slatina Aluminum Plant is at risk of closing.1,300 A total of 1300 employees were on technical unemployment for over two months to the Special Steel Plant in Targoviste. in the near future, either in chemical and petrochemical industry there will be no new jobs. in this section, an example represents the problems of blockage of company Oltchim SA Rm. Vâlcea, which extended for years, with large accumulations of debts to the state, without the perspective of a privatization of lack of buyers. Neither in the banking field there is no prospects for growth, because in 2014 many banks have closed subsidiaries. The only areas where there have been increases are in the automotive industry and high technology (IT). for example, in 2013, the IT sector had an increase of $4 \%$ compared to 2012. This is because Romania is the only country of European Union which does not tax salary incomes of employees in the respective fields. in the automotive sector, in the automotive industry, although in 2013 the Romanian automobile market has been stagnant to 2012, however, Romania stayed in first place in the European Union on automobile sales.

An insidious cause of unemployment with global effects, specified to the times of today, consists in the discrepancy between technological progress speed installation and training. Following this development, only during the last generation disappeared cinemas, using of landline phones was reduced (phones on the street have disappeared), the number of postal items have restricted, it was eliminated using telegraph, etc. These are only some surface aspects of the present technological revolution, the restrictions being in all economic sectors, from the field of the industrial chemistry to the activity of civil servants. The progress is motivated by the simple fact that instead of employees are preferred robotic services that can work day and night without vacation leaves, maternity, aso and not requiring the payment of additional taxes. On this subject, Carl Frey and Michael Osborne1, in a study entitled "The future of employment", estimated that in the future decade, in Europe will greatly reduce the number of jobs, about 40-60\%. in the opinion of these authors, regarding Romania,

1 Carl Benedikt Frey and Michael Osborne, The future of employment: How susceptible are jobs to computerization?,

University of Oxford, 2013, în adresa: www.oxfordmartin.ox.ac.uk/downloads/academic/The Future of Employment.pdf 
the reduction percentages of jobs reach $62 \%$. The most affected are low-wage positions, which in fact are the most numerous. Therefore, it is necessary a new system of higher education, with focus on technology and automation sectors, to which today in Romania are lowest number of candidates for admission.

A cause of unemployment specific to Romania is the overcharge labor. in a European ladder points concerning contributions paid both employee and by employer, Romania is number six from 26 countries, with a percentage of $46.25 \%$, being exceeded only by Netherlands, the Czech Republic, France, Poland and Albania. At the opposite pole of the Belgium League, United Kingdom and Ireland, where cumulative contributions do not exceed $30 \%$. Higher taxation of work appeared after 1990, due to the explosive evolution of unemployment. The absence of active employment policies, with massive black employments, has led to decrease in the number of contributors in parallel with the rapid growth in the number of retired persons. in this situation, the governments' solution was only to increase social contributions. On the other hand, high percentages of labor taxation have restricted required liquidity for the establishment of new enterprises jobs, and the consumption by decreasing the purchasing power of the population, especially favored black labor growth. According to the estimations of some authors, in Romania their number reached about 3.4 million people1.

To underline on this subject, that in all electoral campaigns after 1990 was argued the necessity of "enlargement of the tax base" with principal respect to the creation of new jobs. This was not sufficiently achieved during any government

Another cause is the insufficiency of foreign and public investments, correlated with the existing unemployment and new jobs requirements. in 2013 , although Romania has attracted foreign investments of 2,388 billion euros, increasing by $22.3 \%$ from 2012, however they were below the net capital inflow since 2008, when they recorded the highest values of 9,496 billion euros, after 1990 - see table no. 4.

Table no. 4

Net inflows foreign

direct investments

Source: National Bank

of Romania reports

\begin{tabular}{|l|l|}
\hline Year & Billion euros \\
\hline 2008 & 9,496 \\
\hline 2009 & 3,488 \\
\hline 2010 & 2,220 \\
\hline 2011 & 1,815 \\
\hline 2012 & 2,138 \\
\hline 2013 & 2,388 \\
\hline & \\
\hline & \\
\hline
\end{tabular}

For example, in 2013 with the help of foreign investment could generate 6.157 jobs, but at a price down $13 \%$ compared to the previous year, when they generated 7.114 jobs. It should be noted that most of these investments take into consideration the privatization through sale of state companies such as: American Airlines Cargo, CFR, Romgaz, Transgaz, Hydro, Nuclear Electrica, Romtelecom and others. for a long time, these units were included in an agreement with the International Monetary Fund for the restructuring of enterprises, but with limited success until now.

Regarding public investment, the present minister delegate for the Budget, Mr. Liviu Voinea, at a meeting of the Commission for Social Dialogue dated 4 March 2014 said that the state investment projects for 2012 were 4.7 billion dollars from a total of 11 billion lei (about 2.5 billion euros), and in 2013 this was of 6 billion lei from a total of about 12 billion lei (about 2.7 billion euro) of the state budget. Basically, the top 20 public investment projects in 2013 are half of the investments in 2012. The duration of the projects is about 12 years, majority of the amounts being allocated for highways and infrastructure works. for example, in 2014, of public investment projects engaged, we can mention: completing the barrage of Constanta port for almost 200 million lei, Oradea airport modernization and the extension Drumul Taberei Subway - Pantelimon in Bucharest with 436 million lei allocated. The auction of this study was gained by companies Association Astaldi Spa -ltaly, FCC - Spain, with Delta ACM and AB Construct companies in Romania. We remark that only for this work, Astaldi company doubled the staff in Bucharest to 400 employees in 2011, before work, at 870 employees in 2013, a total of $85 \%$ of

1 Liviu Voinea, Lucian Albu and collaborators: Informal Economy and its impact on the labor market, published on the internet address: http://www.scribd.com/doc/142168475/Economia-Informala-Si-Impactul-Ei-Asupra-Pietei-Muncii; 
employees being Romanian and $15 \%$ were brought in from Italy. Also, Also, constructors' wages were increased by 20 $25 \%$ in all the associated companies.

But, the biggest investments deficit and of employments jobs is due to insufficient absorption of EU funds allocated to Romania, respectively 19,67 billion Euro and national co-financing (the State budget, local budgets and the private sector), of 9 billion euro for the period 2007-2013. But, in 2007-2013 to the present the absorption of EU funds was deeply deficient. for example, to the seven Operational Programmes, during the period from December 2008 - May 2009, Romania has submitted financing projects for three billion euro, of which were approved projects only one billion euro, but payments to beneficiaries were below 100 million euros. The percentage of absorption was under $5 \%$.

At the end of September 2013, Romania managed to make reimbursements only for 64 million euro compared to 195 million euro, sum that it had be reimbursed by the European Commission. in august 2013, absorption rate of these funds was only $23.46 \%$. Even with this increase, Romania is still last ranking countries in Europe. Subsequently, for the sums allocated for 2011 and 2012, the Romanian Government has made a proposal to accept the formula " $n+3$ ", which was adopted by the Regional Committee of the European Parliament.

If the European Parliament will adopt this measure, then Romania will be able to spend the allocated funds of 2011 until 31 December 2014 and those ones allocated for 2012 will be able to spend up to 31 December 2015. in this way, the risk of losing EU funds will be reduced significantly. With all this development, Romania occupies the last place in the European rankings concerning absorption of funds, with a percentage of $37 \%$ at the end of 2013. in circumstances As compared other countries such as Estonia, Portugal and Lithuania were able to absorb $78 \%$ of EU funds allocated in the budget year 2007-2013 - see table no.5.

Table no. 5 Absorption of EU funds between 2007 - 2013 and money received from EU Member States in the period 2014 -2020, of the European Commission sources

\begin{tabular}{|l|l|l|l|}
\hline $\begin{array}{l}\text { Member } \\
\begin{array}{l}\text { European of the } \\
\text { Union }\end{array}\end{array}$ & $\begin{array}{l}\text { Sums allocated } \\
\text { between } \\
2007-2013 \\
\text { (thousands of } \\
\text { euros) }\end{array}$ & $\begin{array}{l}\text { Percentages } \\
\text { paid by EC* }\end{array}$ & $\begin{array}{l}\text { Sums allocated } \\
\text { for 2014-2020 } \\
\text { (thousands of } \\
\text { euros) }\end{array}$ \\
\hline Estonia & 3.403 & 78 & 3590 \\
\hline Portugal & 21.412 & 78 & 21.465 \\
\hline Lithuania & 6.775 & 78 & 6.323 \\
\hline Ireland & 751 & 70 & 1.139 \\
\hline Greece & 20.210 & 69 & 15.522 \\
\hline Germany & 25489 & 69 & 19235 \\
\hline Sweden & 1.626 & 69 & 2.106 \\
\hline Poland & 67.186 & 67 & 77.567 \\
\hline Luxembourg & 50 & 66 & 60 \\
\hline Latvia & 4.530 & 66 & 4.512 \\
\hline Finland & 1.596 & 66 & 1.466 \\
\hline Austria & 1.204 & 65 & 1.236 \\
\hline Spain & 34.658 & 62 & 28.560 \\
\hline Slovenia & 4.101 & 62 & 3.075 \\
\hline Netherlands & 1.660 & 62 & 1.404 \\
\hline Belgium & 2.064 & 59 & 2.284 \\
\hline & & & \\
\hline
\end{tabular}




\begin{tabular}{|l|l|l|l|}
\hline Hungary & 24.921 & 59 & 21.906 \\
\hline France & 13449 & 58 & 15.353 \\
\hline Cyprus & 612 & 57 & 736 \\
\hline $\begin{array}{l}\text { United } \\
\text { Kingdom }\end{array}$ & 9.891 & 56 & 11.840 \\
\hline Denmark & 510 & 54 & 553 \\
\hline $\begin{array}{l}\text { Czech } \\
\text { Republic }\end{array}$ & 26.526 & 50 & 21.983 \\
\hline Malta & 840 & 49 & 725 \\
\hline Italy & 27.958 & 49 & 32.823 \\
\hline Bulgaria & 6674 & 49 & 7.588 \\
\hline Slovakia & 11.498 & 48 & 13.992 \\
\hline Romania & 19.213 & 37 & 22.994 \\
\hline
\end{tabular}

* Includes sums paid by EC as pre-financing and reimbursement

Insufficient use of EU funds comes from multiple causes that need separate analysis. It should be noted that until 2013 by using only $37 \%$ of the 19.67 billion euro, allocated to Romania, resulting a remaining sum of euro 12.39 billion it could not be capitalize. Such great losses of funds occur in other areas. We refer to ,black job" with fiscal evasion in this area. It is noted that for a population of 20 million inhabitants,, only 4.5 million are employed with legal papers, with an average salary of 1,700 lei per month (about 380 euro) which must support 5.4 million retirees and about 8.5 million children. There are areas where the percentage on ,black job" is usually above $60 \%$, such as: in in IT services, $63 \%$ in machinery and equipment repairing or $66 \%$ in civil engineering, which means that for employees concerned, employers do not pay any form of contribution to the state. Through other forms of tax evasion in 2014, Fiscal Council calculated that only losses to the state budget by not paying taxes on the added value are about 72 billion lei.

Other causes regarding unemployment are income polarization and corruption, that expanded on a large scale. in only 24 years of liberal economy, Romania has the most millionaires and billionaires in RON, USD or EUR that it ever had in its history. in contrast, $90 \%$ of the population the average wage is 1,700 lei per month, with 900 lei minimum wage. in 24 years also developed the steepest downward trend in of the population of 20 million inhabitants, meaning it had in 1968. Imbalances are extended not only between rich and poor, they became visible also between regions because 10 of the 42 counties of this country, produces $70 \%$ of Romania businesses and have $80 \%$ of employees. in this respect, our opinion is not like "millionaires and billionaires down", but how can they be capitalized their resources in national interest.

Note that if you collect all sums that are lost daily basis, only from insufficient absorption of EU funds, of fiscal evasion and from the undeclared work, their total is of 10 times higher than the foreign and public investments in the last 5 years, which shows that the real resources of our country to eradicate unemployment are internal and not external.

Obviously, the question is whether this recession will be unlock, the answer can be only an affirmative one because in the recent Romanian history we can record large economic boom phases, both in the interwar period and in that postwar, performed on completely different socio-political principles. But this subject we'll debate in a future study. 